\title{
IMPLEMENTATION OF MATHEMATICAL EQUATION FOR CALCULATING ALUMINA EXTRACTION FROM BAUXITE TAILING DIGESTION
}

\section{PENERAPAN PERSAMAAN MATEMATIKA UNTUK MENGHITUNG PERSENTASE EKSTRAKSI ALUMINA DARI PROSES EKSTRAKSI AMPAS BAUKSIT}

\author{
HUSAINI \\ R\&D Centre for Mineral and Coal Technology \\ Jalan Jenderal Sudirman 623 Bandung 40211 \\ Phone (022) 6030483, Fax. (022) 6003373 \\ e-mail: husaini@tekmira.esdm.go.id
}

\begin{abstract}
Research on bauxite tailing digestion using pressurized batch reactor at a feed capacity of $86.66 \mathrm{~kg}$ had been conducted. Bauxite with -150 mesh of particle size is reacted with $42.15 \mathrm{~kg}$ of caustic soda $(433.49 \mathrm{~g} / \mathrm{l})$ at $140^{\circ} \mathrm{C}$ for 1.0 to 2.5 hours using steam as heating media. Lime added are varied from 3 to $9 \mathrm{~kg}$. After processing for a certain period of time, slurry product is transfered into a mixer. To evaluate percent extraction of $\mathrm{Al}_{2} \mathrm{O}_{3}$ from this process, the height of slurry level in the mixer, densities of the slurry, filtrat, and solid residue are measured and determined. The head sample of bauxite, filtrate and residue are analysed by using wet method to obtain $\mathrm{Al}_{2} \mathrm{O}_{3}$ content of each sample taken from the mixer. There are four equations that are used for obtaining the alumina extraction, namely :

$\mathrm{V}_{\mathrm{sl}}=4.176 \mathrm{x}+15.83$

$W s \mathrm{l}=(4.176 \mathrm{x}+15.83) \rho s \mathrm{I}$

$S=(\rho s \mathrm{l}-\rho \mathrm{l}) /(\rho \mathrm{s}-\rho \mathrm{l})(\rho \mathrm{s} / \rho \mathrm{l}))^{*} 100 \%$

$E=\left[10(4.176 x+15.83)\left[1-\left(\rho_{s l}-\rho_{I}\right) /\left(\rho_{S}-\rho_{I}\right)\right]^{*}\left[c_{I} / F x_{F}\right] \%\right.$

The calculation results show that by increasing lime added into the slurry, percent yield of alumina extraction tend to decrease from $46.63 \%$ for $3 \mathrm{~kg}$ of lime to $15.84 \%$ by using $9 \mathrm{~kg}$ of lime. Whereas by varying reaction time between 1.0-2.5 hours, percent yield of alumina extraction are fluctuation in the range of $42.07-60.54 \%$, and the highest result was obtanined for 1,5 hours of reaction time. By implementing those four equations above for evaluating the data, we do not need to weigh the slurry in the reactor.
\end{abstract}

Keywords: bauxite tailing, digestion, alumina extraction, mathematical model, Bayer process.

\begin{abstract}
ABSTRAK
Penelitian pelarutan bauksit dengan menggunakan reaktor batch bertekanan pada kapasitas 86,66 $\mathrm{kg}$ umpan telah dilakukan. Bauksit berukuran butir -150 mesh direaksikan dengan 42,15 $\mathrm{kg}$ sodium hidroksida (konsentrasi $433,49 \mathrm{~g} / \mathrm{L}$ ) pada suhu $140^{\circ} \mathrm{C}$ selama 1.0 sampai 2.5 jam menggunakan media pemanas uap air. Kapur yang digunakan divariasikan mulai 3 sampai dengan $9 \mathrm{~kg}$. Setelah proses berlangsung dalam jangka waktu tertentu, produk sluri dipompa ke dalam Mixer. Untuk mengevaluasi persen ekstraksi $\mathrm{Al}_{2} \mathrm{O}_{3}$ dari proses ini, tinggi permukaan sluri dalam reaktor, densitas sluri, filtrat dan padatan residu diukur dan ditentukan. Umpan bauksit, filtrat, dan residu dianalisis menggunakan cara basah untuk menentukan kandungan $\mathrm{Al}_{2} \mathrm{O}_{3}$ dalam setiap percontoh yang diambil dari Mixer. Ada 4 persamaan yang digunakan untuk menghitung persen ekstraksi dari proses pelarutan yaitu :

$V_{s l}=4.176 x+15.83$
\end{abstract}




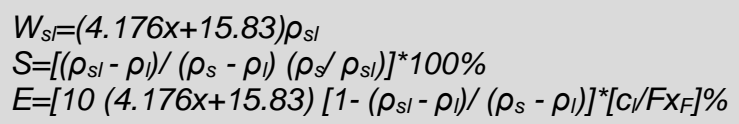

Hasil perhitungan dengan menggunakan persamaan di atas menunjukkan bahwa penambahan kapur yang semakin tinggi memberikan persen ekstraksi alumina yang semakin rendah yaitu dari $46.63 \%$ dengan dosis kapur $3 \mathrm{~kg}$ turun menjadi 15,84\% dengan penambahan kapur sebesar $9 \mathrm{~kg}$. Sedangkan untuk variasi waktu reaksi antara 1-2,5 jam, persen ekstraksi alumina mengalami fluktuasi dalam rentang nilai 42,07-60,54\%, dan hasil tertinggi dicapai dalam waktu 1,5 jam dengan persen ekstraksi alumina sebesar 60,54\%. Dengan menerapkan keempat persamaan di atas untuk mengevalusi data, penimbangan sluri dalam reaktor tidak diperlukan.

Kata kunci: ampas bauksit, pemasakan, ekstraksi alumina, model matematika, proses Bayer.

List of Symbols :

$\mathrm{V}_{\mathrm{sl}}$ is volume of slurry in the mixer (litre) $x$ is height of slurry level in the mixer $(\mathrm{cm})$ $\mathrm{W}_{\mathrm{sl}}$ is weight of slurry in the mixer $(\mathrm{kg})$

$\mathrm{S}$ is solid percentage of slurry (\%)

$\rho_{\mathrm{sl}}$ is density of slurry $(\mathrm{kg} / \mathrm{l})$

$\rho_{\mathrm{s}}$ is density of residue $(\mathrm{kg} / \mathrm{l})$

$\rho_{\mathrm{l}}$ is density of filtrate $(\mathrm{kg} / \mathrm{l})$

$\mathrm{C}_{\mid}$is concentration of $\mathrm{Al}_{2} \mathrm{O}_{3}$ in filtrate $(\mathrm{g} / \mathrm{l})$

$E$ is extraction of $\mathrm{Al}_{2} \mathrm{O}_{3}(\%)$

\section{INTRODUCTION}

Bauxite is a heterogeneous material principally composed of aluminum oxide minerals and some impurities minerals. It is usually comprised of gibbsite, aluminogoethite, hematite, kaolin, quartz, and minor boehmite (Pan, et all., 2012) and is being used in chemical, cement, refractory, abrasive, fertilizer, steel and other industries (Tariq, et all. 2014). There are some bauxite companies which have been operating in Indonesia such as PT. Aneka Tambang and PT. Harita. Those companies usually use open pit method to mine crude bauxite from its deposit in the earth. They use backhoe to dig crude bauxite and the product mine is then transferred by dump truck to washing plant area. Washing is one of methods that is usually used to upgrade alumina content of bauxite by separating primary mineral impurities like clay, silica, iron, and titanium that are attached on the surface of crude bauxite (Palmer, et all., 2009). Trommol screen is a common equipment used to wash and screen coarse bauxite from very fine particles size by supporting pressurized spray water. By using water spraying and screening, smaller particles attached on the surface of crude bauxite is easy to separate. Therefore, there are two products of washing, namely washed bauxite having $+2 \mathrm{~mm}$ of particle size with high content of alumina and tailing having $-2 \mathrm{~mm}$ of particle size with lower content of alumina. The amount of tailing resulting from crude bauxite washing is a lot, it is about $50 \%$ by weight of crude bauxite that is being washed. PT. Antam is now producing washed bauxite about 750,000 ton per year to supply $P T$. Indonesia Chemical Alumina that has being produced chemical grade alumina with a capacity of around 300,000 tons alumina per year using Bayer's method. So, the amount of crude bauxite to be mined by PT. Antam is around 1,500,000 tons per year and this will generate tailing about 750,000 tons per year.

Up to now, this tailing is dumped into tailing pond and has not been utilized yet. So, it will endanger the environment if it is not handled properly. Besides, it needs very big space for preparing pond to collect tailing from bauxite washing, so it will be costly. In the effort to minimize the problem, Mineral and Coal Technology Research and Development Center has been trying to process tailing to become sodium aluminate solution that can be utilized as a raw material for polyaluminum chloride, alum, or synthetic zeolite production.

To make it easy and practices in carrying out research activities on tailing digesting, especially in evaluating the data obtained 
from research, a mathematical model is used to determine some parameter such as slurry volume, slurry weight, solid percentage, and percent extraction of alumina. This paper will discuss the result of the reasearch on digesting tailing from bauxite washing originited from Meliau, West Kalimantan, Indonesia.

Bayer's process is the only one technology applied all over the world for producing alumina economically. There are four-steps of processing to produce alumina from bauxite, namely digesting, filtering, precipitation, and calcination (Kopeliovich, 2012, Kontopoulos, et all., 1997). Fine bauxite (-150 mesh of particle size) is digested in pressurized reactor (autoclave) at certain temperature and pressure, depending on type of bauxite which is processed. Usually, the digesting temperature in the range of $140-160^{\circ} \mathrm{C}$ for gibbsite type and $220-280^{\circ} \mathrm{C}$ for bochmite type of bauxite. Chemical reaction occured in bauxite digestion is as follows (Donoghue, 2014, Reyner-Canham, et.all.,1996):

$$
\begin{aligned}
& \mathrm{Al}_{2} \mathrm{O}_{3} \cdot 3 \mathrm{H}_{2} \mathrm{O}+2 \mathrm{NaOH}_{\mathrm{aq}} \rightarrow \underset{4 \mathrm{~N}_{2} \mathrm{O} \cdot \mathrm{Al}_{2} \mathrm{O}_{3}+}{4 \mathrm{H}_{2} \mathrm{O}} \\
& \text { (sodium aluminate) }
\end{aligned}
$$

In addition to dissolve alumina content, caustic soda will also react with reactive silica contained in the bauxite tailing as described in chemical reaction bellows (Palmer et al., 2009):

$$
2 \mathrm{NaOH}+\mathrm{SiO}_{2} \rightarrow \underset{\begin{array}{l}
\mathrm{Na}_{2} \mathrm{O} \cdot \mathrm{SiO}_{2}+\mathrm{H}_{2} \mathrm{O} \\
\text { (sodium silicate) }
\end{array}}{\mathrm{Sin}}
$$

Then sodium aluminate will react with sodium silicate with chemical reaction bellows:

$\mathrm{Na}_{2} \mathrm{O} \cdot \mathrm{Al}_{2} \mathrm{O}_{3}+2\left(\mathrm{Na}_{2} \mathrm{O} \cdot \mathrm{SiO}_{2}\right)+4 \mathrm{H}_{2} \mathrm{O}=$ $\mathrm{Na}_{2} \mathrm{O} \cdot \mathrm{Al}_{2} \mathrm{O}_{3} \cdot 2 \mathrm{SiO}_{2}+2 \mathrm{H}_{2} \mathrm{O}+4 \mathrm{NaOH}$ (sodalite)

Sodalite will combine with red mud to be wasted that should be managed properly. Based on a thermodynamic point of view, bauxite digestion primarily is controlled by alumina mineral phase, caustic concentration, and digestion temperature (Hond, et all., 2007).

In this research, tailing to be processed is belong to gibbsite type of bauxite, therefore the temperatur of digesting that has been used around $140^{\circ} \mathrm{C}$ is suitable for this process. Product of digesting is slurry form containing sodium aluminate and red mud. By filterring using filter press, clear sodium aluminate solution is produced separated from cake of red mud (The International Aluminium Institute, 2012). To convert sodium aluminate into alumina trihydrate $\left[\mathrm{Al}(\mathrm{OH})_{3}\right]$ precipitate, for conventional method, seed of fine $\mathrm{Al}(\mathrm{OH})_{3}$ is added into sodium aluminate solution during hydrolisys process that can achieve precipitation ratio of $55 \%$. Hydrolysis is conducted at a certain temperature ; boehmite can be precipitated at the temperature above $90^{\circ} \mathrm{C}$ for isothermal condition and between $70-90^{\circ} \mathrm{C}$ for non isothermal condition. The yield of boehmite precipitation is 35 - 40\% (Kontopoulos, et al., 1997). The alumina concentration in the supersaturated sodium aluminate solution is in between $80-200 \mathrm{~g} / \mathrm{l}$ with best value $132 \mathrm{~g}$ $\mathrm{Al}_{2} \mathrm{O}_{3} /$. Caustic concentration in the supersaturated sodium aluminate solution is varying between $50-250 \mathrm{~g} / \mathrm{l}$ with best value 120g/l (Kontopoulos, et al., 1997). By adding methanol, a proper temperature for sodium aluminate hydrolysis is about $64.5{ }^{\circ} \mathrm{C}$ with maximum equilibrium precipitation ratios is about $83 \%$ after $24 \mathrm{~h}$ and stated that the lower viscosity at higher temperature is a factor that enhances the yield and makes the effect of temperature is small (Zhang, et al., 2009).

The washed product of $\mathrm{Al}(\mathrm{OH})_{3}$ is then dried and calcined at hight temperature in the range of $1010-1260^{\circ} \mathrm{C}$ in a rotary kiln or fluidized bed calciners to drive off the molecules of hydrated water to become alumina: $\mathrm{Al}_{2} \mathrm{O}_{3} 3 \mathrm{H}_{2} \mathrm{O}=\mathrm{Al}_{2} \mathrm{O}_{3}+3 \mathrm{H}_{2} \mathrm{O}$ or $2 \mathrm{Al}(\mathrm{OH})_{3}=2 \mathrm{Al}_{2} \mathrm{O}_{3}+3 \mathrm{H}_{2} \mathrm{O}$ (Kopeliovich, 2012; Marsh, 2009, Kontopoulos, et al., 1997).

To improve Bayer's process performance, lime or its derivatives can be used to reduce caustic soda consumption, especially at higher temperatures. Lime increases the desilication efficiency of the bauxite digesting. In addition to reduce silica content in sodium aluminate solution, lime can also minimize impurities like carbonate, silica, and phosphor of this solution (Pan et al., 2012).

Sodium aluminate solution is most widely used in municipal drinking water and waste water treatment systems as coagulating agent to improve flocculation, and for 
removing dissolved silica and phosphates. It is also used in the paper industry, for fire brick production, alumina production and synthetic zeolites. In construction technology, sodium aluminate is employed to accelerate the solidification of concrete, mainly when working during frost.

\section{METHODOLOGY}

Bauxite used for the experiment is from Meliau, West Kalimantan having -150 mesh of particle size and having average chemical composition of $\mathrm{Al}_{2} \mathrm{O}_{3} 27.89 \%$, total $\mathrm{SiO}_{2}$ $50.79 \%$, free $\mathrm{SiO}_{2} 39.49 \%$, reactive $\mathrm{SiO}_{2}$ $11.3 \%$, and $\mathrm{Fe}_{2} \mathrm{O}_{3} 7.98 \%$. Raw materials used are bauxite tailing (under size of bauxite washing by using rotary drum scrubber), caustic soda, lime and water. The mixture consisting of $86.66 \mathrm{~kg}$ bauxite tailing, $42.15 \mathrm{~kg} \mathrm{NaOH}, 87.5 \mathrm{~kg}$ water and lime at certain weight are put into an autoclave. The mixture in the autoclave is then heated and contacted directly with steam generated from boiler. The steam having pressure about 4 atm and temperature around $140^{\circ} \mathrm{C}$ are used for heating media. Variables observed include lime doses and reaction time. Lime doses vary from 3 to $9 \mathrm{~kg}$ for $86.66 \mathrm{~kg}$ of feed and reaction time varies from 1 to 2.5 hours (Table 1). After digesting process is finished, slurry product from autoclave is flown into the sump and then diluted with water before pumping into Mixer. Slurry level in the Mixer is then measured to calculate slurry volume in the Mixer. After that, the slurry in the Mixer is sampled and divided into two parts, one sample for filtering to get filtrate and red mud, another sample for physical analysis. Densities and alumina contents of all those samples including slurry, filtrate, and red mud are then determined. Using all data obtained, percent extraction of alumina can be calculated. There are four steps to obtain percent extraction of alumina, namely a) determination of slurry volume using equation (1); b) determination of slurry weight using equation (2); c) determination of solid percentage of the slurry using equation (3); and d) calculation of percent extraction of alumina using equation (4). Equipments used for conducting experiment consist of boiler, ball mill, sump, autoclave, mixer, and filter press (Figure 1). The flow diagram of experiment is shown in Figure 2.
Firstly, bauxite tailing is ground into -150 mesh using ball mill, followed by digestion of bauxite tailing by using caustic soda in autoclave, after that transfering slurry of digestion product from autoclave into Mixer, finally filterring slurry by using filter press to get clear sodium aluminate solution separated from red mud. Mixer has a specification as follows : diameter $76.50 \mathrm{~cm}$, height $157 \mathrm{~cm}$, total volume $700 \mathrm{~L}$.

\section{RESULTS AND DISCUSSION}

To determine percent extraction of $\mathrm{Al}_{2} \mathrm{O}_{3}$ from bauxite tailing digesting, some data should be collected, those are slurry volume, filtrate volume, slurry weight, solid percentage, densities of slurry, filtrate and residue. There are four equation to be used to calculate slurry volume, slurry weight, solid percentage, and alumina percent extraction that will be explained belows.

\section{Determination of Mixer Volume}

To determine Mixer volume at any height level, callibration method should be conducted. Firstly, empty a Mixer and acquire zero point in the system. Secondly, a certain volume of water is put into Mixer and write down the height of water level in Mixer. Thirdly, repeat it in this way until the relation between water volume and height water level along the height of Mixer is collected and then make a graph tabulation to get an equation.

For knowing slurry volume resulting from digesting bauxite with caustic soda using pressurized reactor, digested slurry product is pumped into Mixer where its volume has been callibrated. Mixer volume is a function of its height level as shown in Tabel 1. By plotting the height of slurry level versus slurry volume, it can obtain a stright line equation that is $V_{\mathrm{sl}}=4.176 \mathrm{x}+15.83$ as shown in Figure 3 , where Vsl is slurry volume and $x$ is the height of slurry level in Mixer. From Figure 3 , the slurry volume increases by the increase of height slurry level in Mixer. The highest slurry level in Mixer is $157 \mathrm{~cm}$ which correlates with slurry volume of $680 \mathrm{~L}$. On the other hand, the height slurry level of 0 $\mathrm{cm}$ shows slurry volume of $20 \mathrm{~L}$, it means that the bottom part of Mixer has volume of $20 \mathrm{~L}$. 


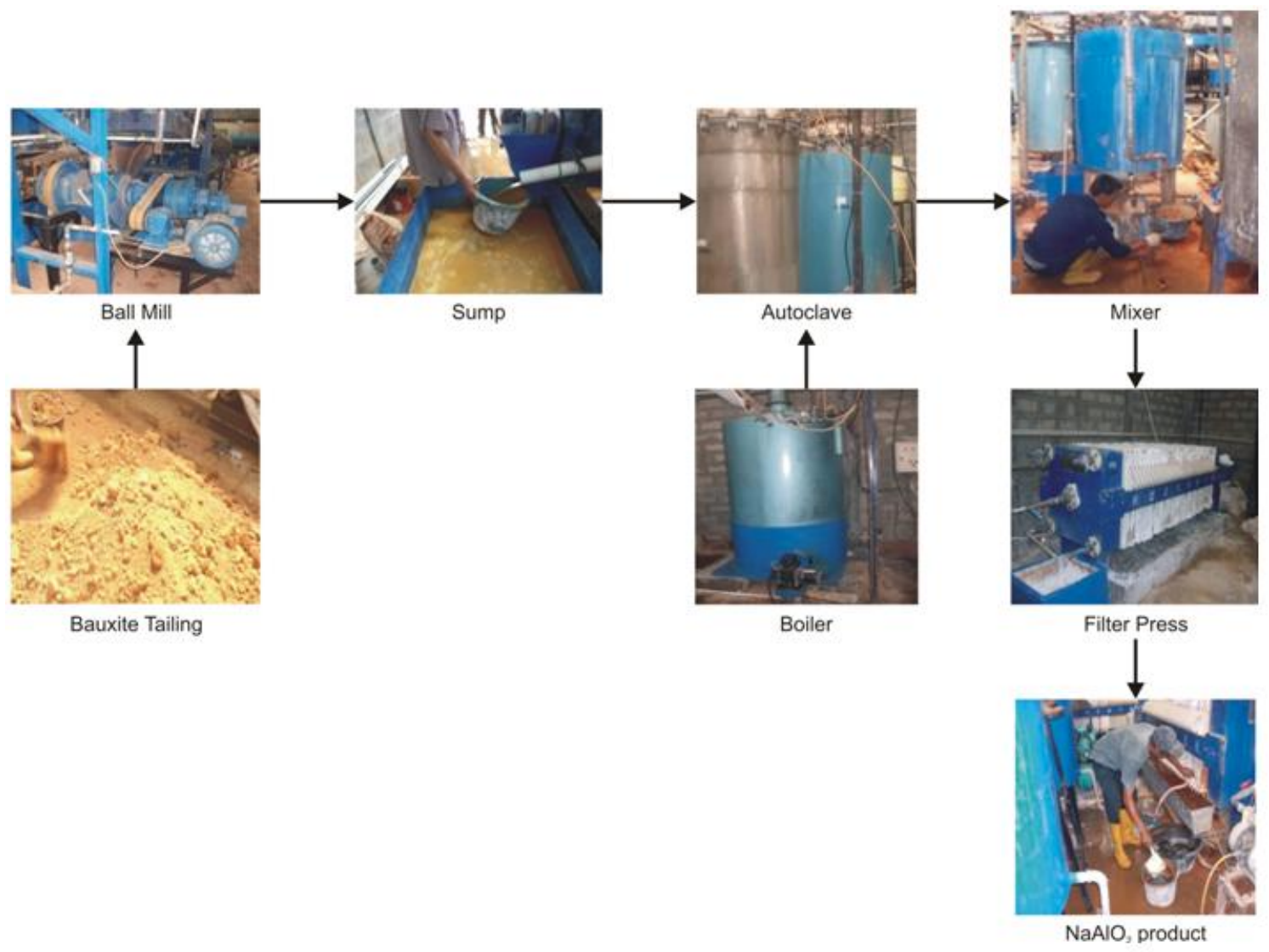

Figure 1. Equipment used for experiment

Tabel 1. Condition of digesting bauxite tailing

\begin{tabular}{|c|c|c|c|c|c|c|c|c|c|}
\hline No. of the experiment & 1 & 2 & 3 & 4 & 5 & 6 & 7 & 8 & 9 \\
\hline Reaction time (hour) & 1 & 1 & 1 & 1 & 1 & 1 & 1.5 & 2 & 2.5 \\
\hline Lime (kg) & 3.0 & 4.5 & 6.0 & 7.5 & 9.0 & 3.0 & 3.0 & 3.0 & 3.0 \\
\hline Weight of feed (kg) & 86.66 & 86.66 & 86.66 & 86.66 & 86.66 & 86.66 & 86.66 & 86.66 & 86.66 \\
\hline $\mathrm{Al}_{2} \mathrm{O}_{3}$ grade of feed $=x F(\%)$ & 27.89 & 27.89 & 27.89 & 27.89 & 27.89 & 27.89 & 27.89 & 27.89 & 27.89 \\
\hline $\begin{array}{l}\mathrm{NaOH} \text { used (purity 99\%) } \\
(\mathrm{kg})\end{array}$ & 42.15 & 42.15 & 42.15 & 42.15 & 42.15 & 42.15 & 42.15 & 42.15 & 42.15 \\
\hline $\mathrm{H}_{2} \mathrm{O}$ consumption $(\mathrm{kg})$ & 87.5 & 87.5 & 87.5 & & 87.5 & 87.5 & 87.5 & 87.5 & 87.5 \\
\hline $\mathrm{NaOH}$ concentration $(\mathrm{g} / \mathrm{L})$ & 433.49 & 433.49 & 433.49 & 433.49 & 433.49 & 433.49 & 433.49 & 433.49 & 433.49 \\
\hline Initial solid percentage (\%) & 40.56 & 40.56 & 40.56 & 40.56 & 40.56 & 40.56 & 40.56 & 40.56 & 40.56 \\
\hline \multicolumn{10}{|l|}{ Desilication condition: } \\
\hline - Steam pressure (atm) & $2-3$ & $2-3$ & $2-3$ & $2-3$ & $2-3$ & $2-3$ & $2-3$ & $2-3$ & $2-3$ \\
\hline - Temperature of slurry $\left({ }^{\circ} \mathrm{C}\right)$ & $50-60$ & $50-60$ & $50-60$ & $50-60$ & $50-60$ & $50-60$ & $50-60$ & $50-60$ & $50-60$ \\
\hline - Reaction time (minute) & $15-20$ & $15-20$ & $15-20$ & $15-20$ & $15-20$ & $15-20$ & $15-20$ & $15-20$ & $15-20$ \\
\hline $\begin{array}{l}\text { - Duration from start to } \\
\text { maximum pressure (minute) }\end{array}$ & 45 & 45 & 45 & 45 & 45 & 45 & 45 & 45 & 45 \\
\hline \multicolumn{10}{|l|}{ Digesting condition: } \\
\hline - Steam pressure (atm) & 4.4 & 4.4 & 4.4 & 4.4 & 4.4 & 4.4 & 4.4 & 4.4 & 4.4 \\
\hline - Temperature of slurry $\left({ }^{\circ} \mathrm{C}\right)$ & 120 & 120 & 120 & 120 & 120 & 120 & 120 & 120 & 120 \\
\hline - Reaction time (minute) & 2 & 2 & 2 & 2 & 2 & 1 & 1.50 & 2.00 & 2.50 \\
\hline
\end{tabular}


INDONESIAN MINING JOURNAL Vol. 19, No. 1, February $2016: 27$ - 38

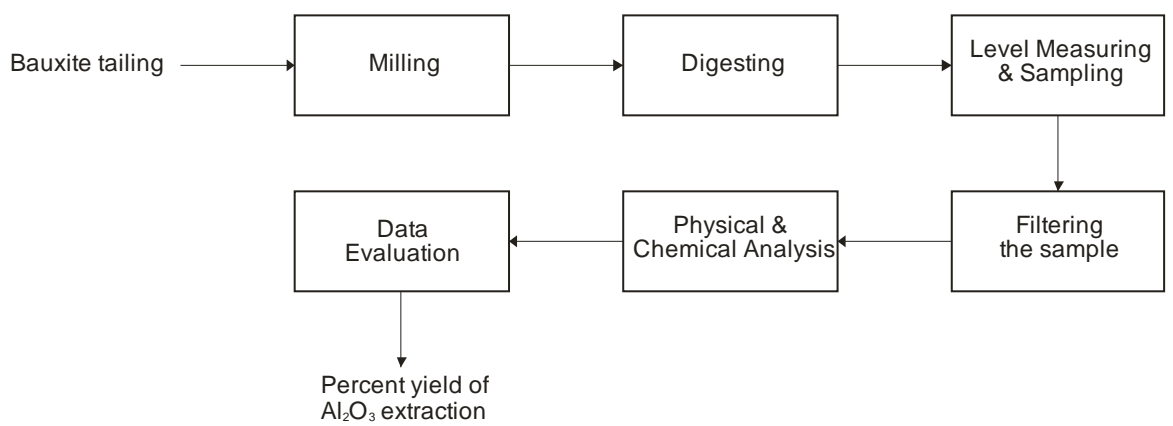

Figure 2. Flow sheet for bauxite tailing digesting and method for experimental data evaluation

Tabel 2. Relation between height of slurry level with volume of slurry in Mixer

\begin{tabular}{|c|c|c|c|}
\hline $\begin{array}{l}\text { Height slurry level } \\
(\mathrm{cm})\end{array}$ & $\begin{array}{l}\text { Volume of slurry } \\
\text { (L) }\end{array}$ & $\begin{array}{l}\text { Height slurry level } \\
(\mathrm{cm})\end{array}$ & $\begin{array}{c}\text { Volume of slurry } \\
\text { (L) }\end{array}$ \\
\hline 157 & 680 & 81 & 350 \\
\hline 155 & 670 & 79 & 340 \\
\hline 153 & 660 & 76 & 330 \\
\hline 151 & 650 & 74 & 320 \\
\hline 149 & 640 & 72 & 310 \\
\hline 147 & 630 & 69 & 300 \\
\hline 145 & 620 & 66 & 290 \\
\hline 143 & 610 & 63 & 280 \\
\hline 141 & 600 & 61 & 270 \\
\hline 138 & 590 & 59 & 260 \\
\hline 135 & 580 & 56 & 250 \\
\hline 132 & 570 & 53 & 240 \\
\hline 129 & 560 & 51 & 230 \\
\hline 127,5 & 550 & 49 & 220 \\
\hline 125,5 & 540 & 46 & 210 \\
\hline 123,5 & 530 & 44 & 200 \\
\hline 121 & 520 & 42 & 190 \\
\hline 118 & 510 & 39 & 180 \\
\hline 116 & 500 & 37 & 170 \\
\hline 114 & 490 & 34 & 160 \\
\hline 111 & 480 & 31 & 150 \\
\hline 109 & 470 & 29 & 140 \\
\hline 107 & 460 & 27 & 130 \\
\hline 104 & 450 & 25 & 120 \\
\hline 102 & 440 & 22 & 110 \\
\hline 99 & 430 & 20 & 100 \\
\hline 97 & 420 & 18 & 90 \\
\hline 95 & 410 & 15 & 80 \\
\hline 92 & 400 & 13 & 70 \\
\hline 90 & 390 & 10 & 60 \\
\hline 88 & 380 & 8 & 50 \\
\hline 85 & 370 & 6 & 40 \\
\hline \multirow[t]{2}{*}{83} & 360 & 3 & 30 \\
\hline & & 0 & 20 \\
\hline
\end{tabular}




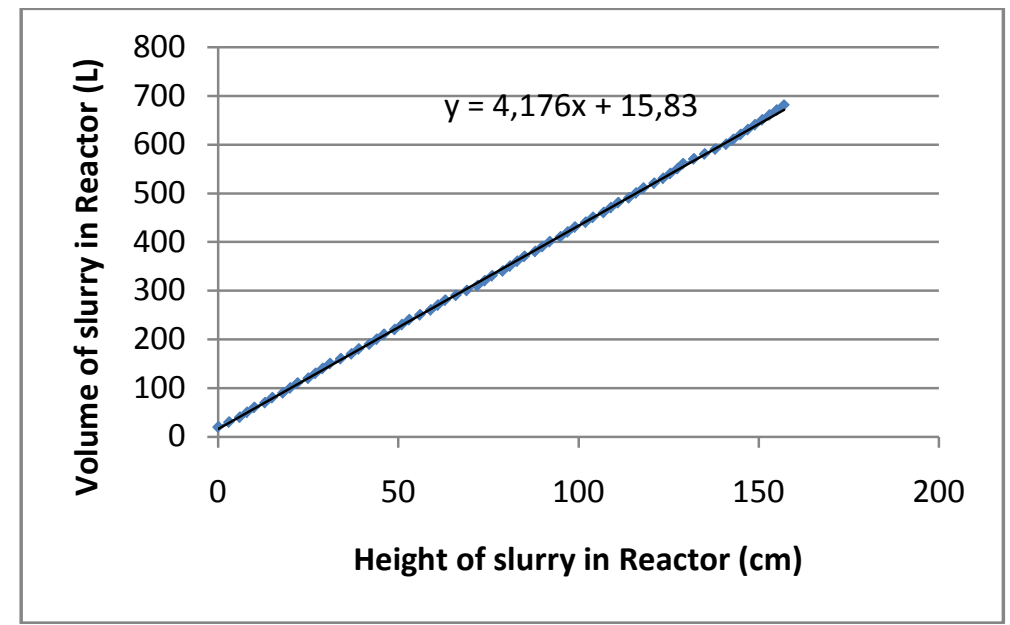

Figure 3. Relation between height of slurry level with slurry volume in Mixer

\section{Determination of Slurry Volume in Mixer}

Slurry level $(x)$ in Mixer obtained from this experiment is shown in Table 2. By using equation : $\mathrm{V}_{\mathrm{sl}}=4.176 \mathrm{x}+15.83$, the slurry volume at any digesting condition can be determined. The complete data of the slurry volume are shown in Table 2.

\section{Determination of Slurry Weight in Mixer}

Slurry weight at a certain volume in Mixer can be calculated by multiplying slurry volume $\left(\mathrm{V}_{\mathrm{sl}}\right)$ with slurry density $\left(\rho_{\mathrm{sl}}\right)$. So, the formula can be written down as follows:

$\mathrm{W}_{\mathrm{sl}}=\mathrm{V}_{\mathrm{sl}} \quad \rho_{\mathrm{sl}} \quad$ Therefore : $W_{\mathrm{sl}}=(4.176 \mathrm{x}+15.83) \rho_{\mathrm{sl}}$. The complete data of the slurry weight are shown in Table 3.

\section{Determination of Solid Weight in Mixer}

Solid weight can be obtained as follows: filtrate volume is slurry volume minus solid volume

$\mathrm{V}_{\mathrm{l}}=\mathrm{V}_{\mathrm{sl}}-\mathrm{V}_{\mathrm{s}}$

$\mathrm{W}_{\mathrm{s}}=\mathrm{W}_{\mathrm{sl}}-\mathrm{W}_{\mathrm{I}}$

$\mathrm{W}_{\mathrm{s}}=\mathrm{V}_{\mathrm{s}} \rho_{\mathrm{s}}$

$\mathrm{W}_{\mathrm{sl}}=\mathrm{V}_{\mathrm{sl}} \rho_{\mathrm{sl}}$

$W_{1}=V_{1} \rho_{1}$

$\mathrm{V}_{\mathrm{s}} \cdot \rho_{\mathrm{s}}=\left(\mathrm{V}_{\mathrm{sl}} \rho_{\mathrm{sl}}-\mathrm{V}_{\mathrm{l}} \rho_{\mathrm{l}}\right)$

$\left.V_{s} \cdot \rho_{s}=\left[V_{s l} \rho_{s l}-\left(V_{s l}-V_{s}\right) \cdot \rho_{l}\right)\right]$

$\mathrm{V}_{\mathrm{s}} \cdot \rho_{\mathrm{s}}=\left(\mathrm{V}_{\mathrm{sl}} \rho_{\mathrm{sl}}-\mathrm{V}_{\mathrm{sl}} \rho_{\mathrm{l}}+\mathrm{V}_{\mathrm{s}} \rho_{\mathrm{l}}\right)$

$V_{s}\left(\rho_{s}-\rho_{l}\right)=V_{s l}\left(\rho_{s l}-\rho_{l}\right)$

$\left.\mathrm{V}_{\mathrm{s}}=\mathrm{V}_{\mathrm{sl}}\left(\rho_{\mathrm{sl}}-\rho_{\mathrm{I}}\right)\right] /\left[\left(\rho_{\mathrm{s}}-\rho_{\mathrm{I}}\right)\right.$

$W_{s}=\left[V_{s l}\left(\rho_{s l}-\rho_{l}\right) /\left(\rho_{s}-\rho_{l}\right)\right] \rho_{s}$

$W_{s}=\left[(4.176 x+15.83)\left(\rho_{s l}-\rho_{l}\right) /\left(\rho_{s}-\rho_{l}\right)\right] \rho_{s}$

The complete data of the solid weight are shown in Table 3.
Determination of Solid Percent in Mixer (Oxana Fox, 2016)

$\mathrm{W}_{\mathrm{sl}}=\mathrm{V}_{\mathrm{sl}} \rho_{\mathrm{sl}}$

Solid percentage $(\%)=($ Solid weight/Slurry weight) $\times 100 \%$

$\mathrm{S}=\mathrm{W}_{\mathrm{S}} \mathrm{W}_{\mathrm{sl}} \times 100(\%)$

Equation of (2) and (3) are substituted to equation (4)

$S=\left[\left(V_{s l}\left(\rho_{s l}-\rho_{l}\right) /\left(\rho_{s}-\rho_{l}\right) \rho_{s}\right) / V_{s l} \rho_{s l}\right] \times 100(\%)$

The complete data of solid percentage of the slurry are shown in Table 2.

\section{Determination of Percent Extraction}

From the above equation is known:

$\mathrm{V}_{\mathrm{I}}=\mathrm{V}_{\mathrm{sl}}-\mathrm{V}_{\mathrm{S}}$

$\mathrm{V}_{\mathrm{s}}=\mathrm{V}_{\mathrm{sl}}\left(\rho_{\mathrm{sl}}-\rho_{\mathrm{I}}\right) /\left(\rho_{\mathrm{s}}-\rho_{\mathrm{I}}\right)$

$\mathrm{V}_{\mathrm{l}}=\mathrm{V}_{\mathrm{sl}}-\left[\mathrm{V}_{\mathrm{sl}}\left(\rho_{\mathrm{sl}}-\rho_{\mathrm{l}}\right) /\left(\rho_{\mathrm{s}}-\rho_{\mathrm{l}}\right)\right]$

$V_{l}=(4.176 x+15.83)-\left(\frac{(4.176 x+15.83)\left(\rho_{s l}-\rho_{l}\right)}{\left(\rho_{s}-\rho_{l}\right)}\right)$

The equation should be used to calculate percent yield of $\mathrm{Al}_{2} \mathrm{O}_{3}$ extraction as follows:

The $\%$ yield of a reaction is the percentage of the product obtained compared to the theoretical maximum (predicted) yield calculated from the balanced equation (Faiers, 2015).

The predicted maximum theoretical yield can be get from a reacting mass calculation. The comparison of the actual yield and the theoretical maximum yield can be expressed as percentage yield. 
PERCENTAGE YIELD $(E)=100 \times \frac{\text { ACTUAL YIELD (e.g. in grams, kg, tonnes) }}{\text { PREDICTED theoretical YIELD (same mass units as above) }}$

In this case : $E$ is alumina weight in filtrate is divided by alumina weight in feed times $100 \%$

$E=\left(V_{l} C_{l} / 1000\right) /\left(F x_{F} / 100\right) \times 100 \%$

$\mathrm{E}=10 \mathrm{~V}_{\mid} \mathrm{C}_{\mid} / \mathrm{Fx_{F }}(\%)$

Where:

$\mathrm{V}_{1}=$ volume of filtrate in Mixer $(\mathrm{L})$

$\mathrm{C}_{\mathrm{l}}=$ concentration of $\mathrm{Al}_{2} \mathrm{O}_{3}$ in filtrate $(\mathrm{g} / \mathrm{L})$

$\mathrm{F}=$ feed weight $(\mathrm{kg})$

$\mathrm{X}_{\mathrm{F}}=\mathrm{Al}_{2} \mathrm{O}_{3}$ grade in feed (\%)

$V_{1}=V_{s l}-\left\{V_{s l}\left(\rho_{s l}-\rho_{l}\right) /\left(\rho_{s}-\rho_{l}\right)\right\}$

$E=10 V_{\mid} c_{\mid} / F_{F}(\%)$

$E=\left[10\left[V_{s^{-}}\left\{V_{s l}\left(\rho_{s l}-\rho_{l}\right) /\left(\rho_{s}-\rho_{l}\right)\right\}^{*}\left[c_{l} / F x_{F}\right]\right.\right.$ (\%)

$E=[10[4.176 x+15.83)-[(4.176 x+15.83)-$ $\left.\left\{\left(\rho_{\mathrm{sl}}-\rho_{\mathrm{l}}\right) /\left(\rho_{\mathrm{s}}-\rho_{\mathrm{l}}\right)\right\}\right]^{\star}\left[\mathrm{c}_{\mathrm{l}} / \mathrm{FX_{F }}\right](\%)$

Where :

$\mathrm{V}_{\mathrm{sl}}$ is volume of slurry in the mixer (litre) $x$ is height of slurry level in the mixer $(\mathrm{cm})$ $\mathrm{W}_{\mathrm{sl}}$ is weight of slurry in the mixer $(\mathrm{kg})$

$\mathrm{S}$ is solid percentage of slurry (\%)

$\rho_{\mathrm{sl}}$ is density of slurry $(\mathrm{kg} / \mathrm{l})$

$\rho_{\mathrm{s}}$ is density of residue $(\mathrm{kg} / \mathrm{l})$

$\rho_{\text {I }}$ is density of filtrate $(\mathrm{kg} / \mathrm{l})$

$\mathrm{C}_{\text {| }}$ is concentration of $\mathrm{Al}_{2} \mathrm{O}_{3}$ in filtrate $(\mathrm{g} / \mathrm{l})$

$E$ is extraction of $\mathrm{Al}_{2} \mathrm{O}_{3}(\%)$

The complete data of percent extraction of $\mathrm{Al}_{2} \mathrm{O}_{3}$ are shown in Table 3 .

The experiment of bauxite tailing digesting with caustic soda was conducted at $140^{\circ} \mathrm{C}$ and pressure of 4 atm. By using four equations mentioned earlier. all data needed to calculate percent extraction of $\mathrm{Al}_{2} \mathrm{O}_{3}$ can be collected as shown in Table 2 .

Based on Tabel 2. the lime doses were plotted againts percent extraction of $\mathrm{Al}_{2} \mathrm{O}_{3}$ and the result is shown in Figure 4 . It can be seen that lime doses provide a significant effect to the extraction of $\mathrm{Al}_{2} \mathrm{O}_{3}$. Percent extraction of $\mathrm{Al}_{2} \mathrm{O}_{3}$ tend to decrease by the increase of lime doses. The value of percent extraction of $\mathrm{Al}_{2} \mathrm{O}_{3}$ is $50.75 \%$ by using $3 \mathrm{~kg}$ of lime. then decrease to $16.77 \%$ by using 9 $\mathrm{kg}$ of lime. The cause of this phenomena could be explained by some reactions that might occur in bauxite tailing digesting as follows:

$\mathrm{Al}_{2} \mathrm{O}_{3}$ contained in bauxite tailing is dissolved with $\mathrm{NaOH}$ to form $\mathrm{Na}_{2} \mathrm{O} \cdot \mathrm{Al}_{2} \mathrm{O}_{3}$ :

$\mathrm{Al}_{2} \mathrm{O}_{3} \cdot 3 \mathrm{H}_{2} \mathrm{O}+2 \mathrm{NaOH}=\mathrm{Na}_{2} \mathrm{O} \cdot \mathrm{Al}_{2} \mathrm{O}_{3}+4$ $\mathrm{H}_{2} \mathrm{O}$

Reactive silica is also contained in bauxite tailing. and lime was added as desilication agent for digesting process in this experiment, therefore it will be dissolved as well with $\mathrm{NaOH}$ and $\mathrm{Ca}(\mathrm{OH})_{2}$ as follows:

$\mathrm{SiO}_{2}+2 \mathrm{NaOH}+\mathrm{Ca}(\mathrm{OH})_{2}=\mathrm{Na}_{2} \mathrm{O}$

$\mathrm{CaO} \cdot \mathrm{SiO}_{2}+2 \mathrm{H}_{2} \mathrm{O}$

Then both products of chemical reaction (1) and (2) will react as follows (Smith, P., 2009):

$\mathrm{Na}_{2} \mathrm{O} \cdot \mathrm{Al}_{2} \mathrm{O}_{3}+2\left(\mathrm{Na}_{2} \mathrm{O}\right.$. $\left.\mathrm{CaO} \cdot \mathrm{SiO}_{2}\right)+2 \mathrm{H}_{2} \mathrm{O}=$ $\mathrm{Na}_{2} \mathrm{O} \cdot 2 \mathrm{CaO} \cdot \mathrm{Al}_{2} \mathrm{O}_{3} .2 \mathrm{SiO}_{2}+4 \mathrm{NaOH}$....(3)

$\mathrm{Na}_{2} \mathrm{O} .2 \mathrm{CaO} . \mathrm{Al}_{2} \mathrm{O}_{3}$. $2 \mathrm{SiO}_{2}$ will precipitate together with red mud.

So, based on both chemical reactions (2) and (3) the more lime added. the more sodium aluminate will react with lime to produce sodalite mixed with red mud. As a result. percent extraction of $\mathrm{Al}_{2} \mathrm{O}_{3}$ will decrease. This result is in line with the statement of Chen et.al. (2007) who stated that the higher reactive silica contained in bauxite tailing. the higher sodalite produced will be; on the other hand. percent exraction $\mathrm{Al}_{2} \mathrm{O}_{3}$ will decrese because of more sodium aluminate produced will react with sodium silicate to produce sodalite. In this research, bauxite tailing used for the experiment contains reactive $\mathrm{SiO}_{2} 11.3 \%$. This content is reasonable high compared to the average content of $0,94-4,9 \%$ in the global bauxite (Alcoa, 2016), because this bauxite tailing contains clay mineral which has a high reactive silica content. 


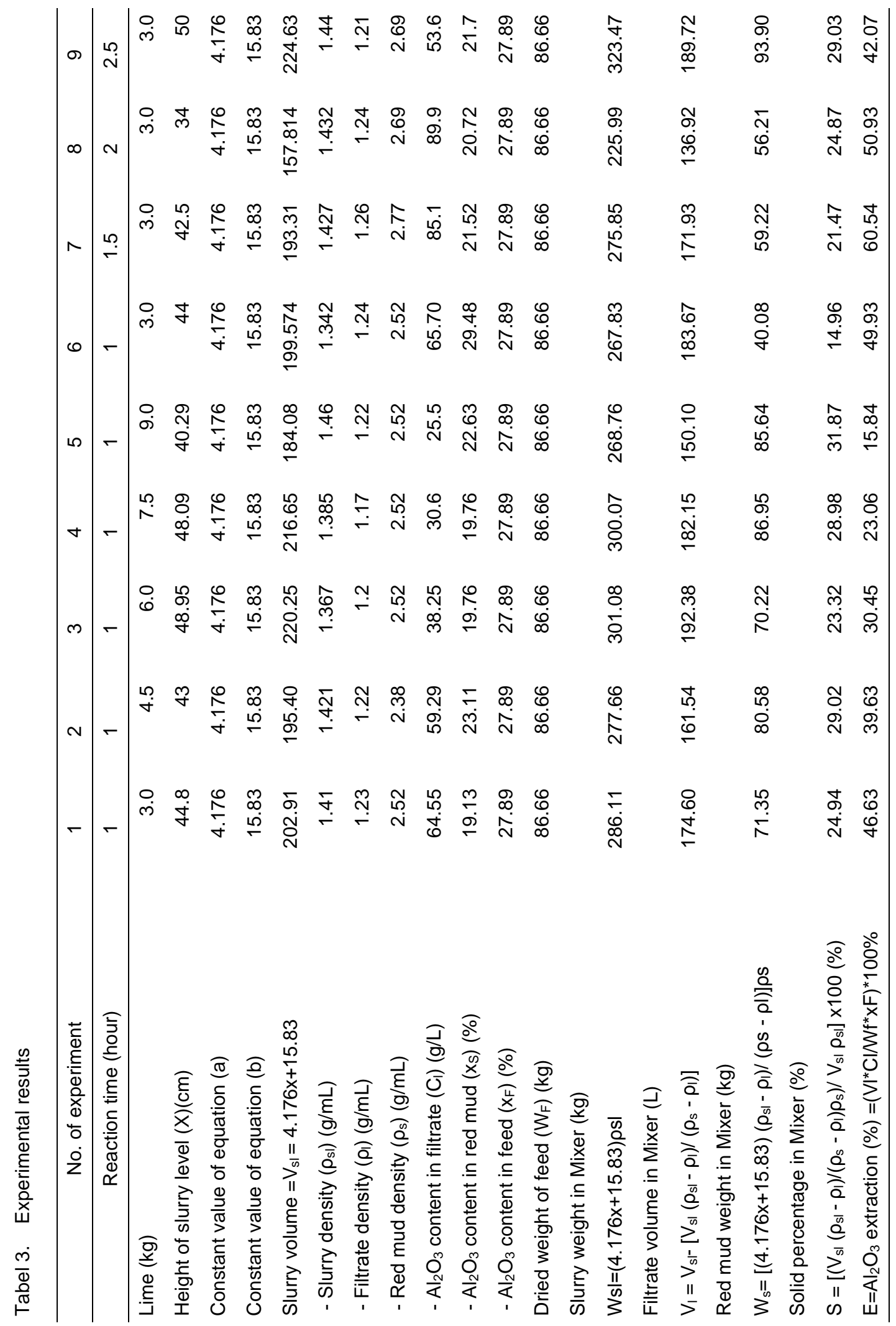


The effect of reaction time on the percent extraction of $\mathrm{Al}_{2} \mathrm{O}_{3}$ is shown in Figure 5. In this research. bauxite tailing ( -150 mesh) was digested with $\mathrm{NaOH}$ at the $140^{\circ} \mathrm{C}$ and pressure 4 atm using steam as heating media. From Figure 4, it can be seen that percent extraction of $\mathrm{Al}_{2} \mathrm{O}_{3}$ tend to fluctuate in the range of $44.29-62.79 \%$ by varying reaction time between 1.0-2.5 hours in which 1.5 hours is the highest value. The decrease of $\mathrm{Al}_{2} \mathrm{O}_{3}$ extraction by the increase time reaction above 1.5 hours may be caused by sodium and/or calcium silicate occured during digesting process react with sodium aluminate solution to form sodalite $\left(\mathrm{Na}_{2} \mathrm{O} .2 \mathrm{CaO} \cdot \mathrm{Al}_{2} \mathrm{O}_{3} .2 \mathrm{SiO}_{2}\right)$ as explained above. So. the longer reaction time, the higher the amount of sodium aluminate that react with sodium silcate will be. As a result, extraction of $\mathrm{Al}_{2} \mathrm{O}_{3}$ will decrease.

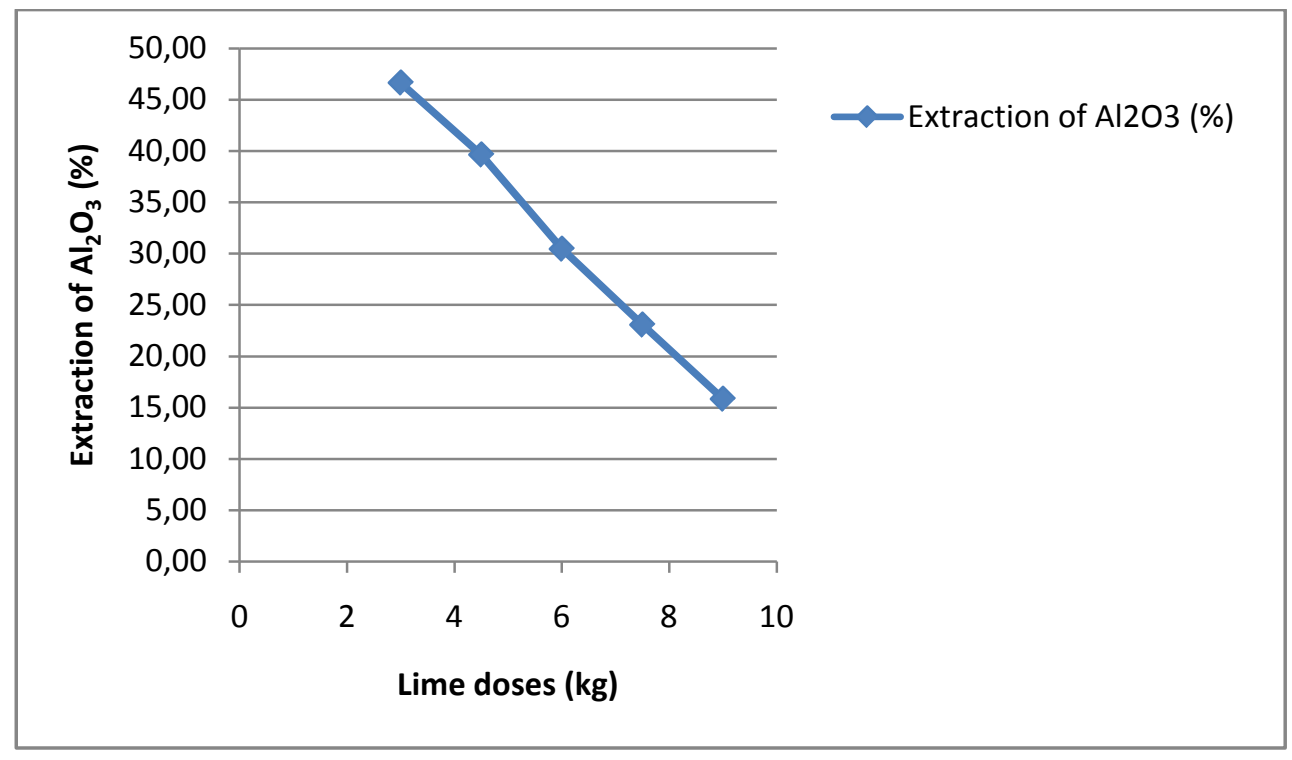

Figure 4. The relation between alum doses versus percent extraction of $\mathrm{Al}_{2} \mathrm{O}_{3}$

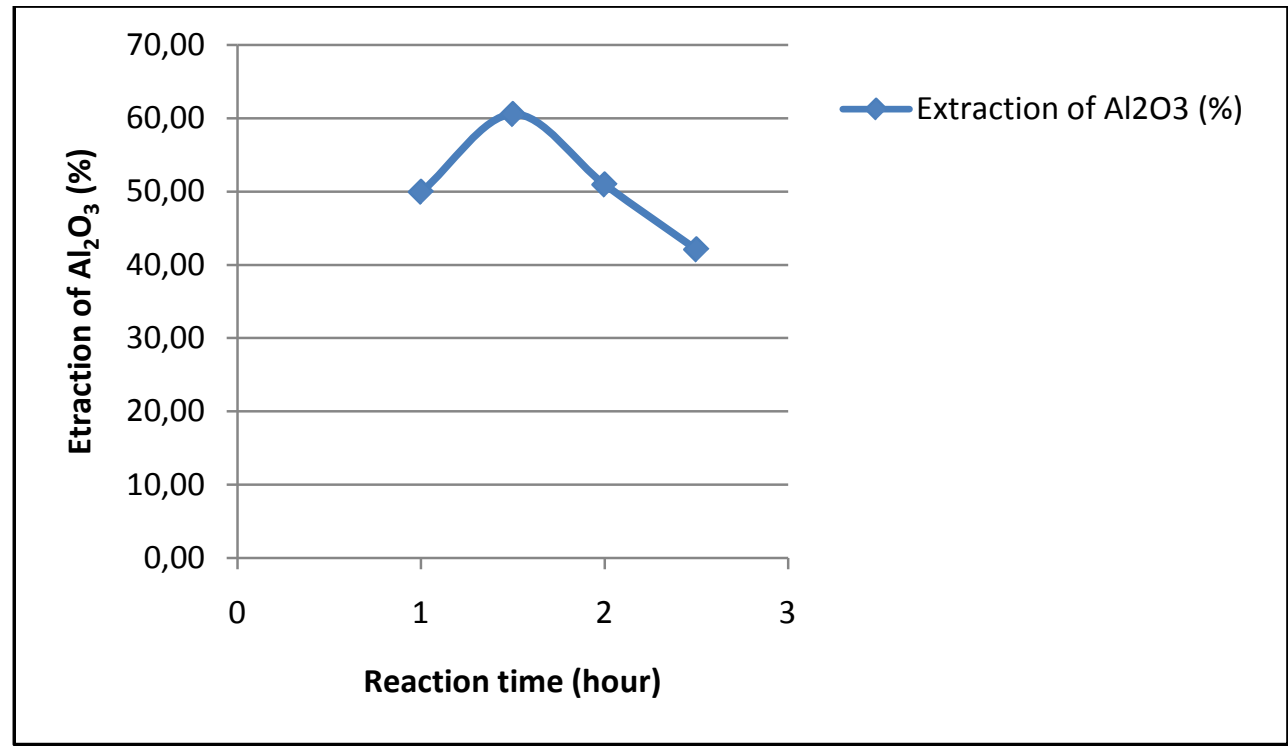

Figure 5. The relation between reaction time versus percent extraction of $\mathrm{Al}_{2} \mathrm{O}_{3}$ 


\section{CONCLUSION}

Percent extraction (yield) of alumina from crude bauxite digesting using caustic soda at $140^{\circ} \mathrm{C}$ and pressure 4 atm can be determined by using four equations without weighing of the slurry obtained from digestion process. Those four equation are $\mathrm{V}_{\mathrm{sl}}=4.176 \mathrm{x}+15.83 ; \mathrm{W}_{\mathrm{sl}}=(4.176 \mathrm{x}+15.83) \rho \mathrm{sl} ;$ $\mathrm{S}=\left[\left(\mathrm{V}_{\mathrm{sl}}\left(\rho_{\mathrm{sl}}-\rho_{\mathrm{I}}\right) /\left(\rho_{\mathrm{s}}-\rho_{\mathrm{I}}\right) \rho_{\mathrm{s}}\right) / \mathrm{V}_{\mathrm{sl}} \rho_{\mathrm{sl}}\right] \times 100(\%)$ and $\mathrm{E}=[10[4.176 \mathrm{x}+15.83)-[(4.176 \mathrm{x}+15.83)-$ $\left.\left\{\left(\rho_{\mathrm{sl}}-\rho_{\mathrm{I}}\right) /\left(\rho_{\mathrm{s}}-\rho_{\mathrm{I}}\right)\right\}\right]^{*}\left[\mathrm{C}_{\mathrm{l}} / \mathrm{Fx}_{\mathrm{F}}\right](\%)$. Some data needed for determination of percent yield of alumina extraction are densities of slury. filtrate. and red mud as well as alumina contents. The first obtained data is slurry volume, followed by slurry weight. slurry solid percentage. and finally calculation of percent yield of alumina extraction. From evaluation of digesting process. it can be concluded that by increasing lime added into the process. percent yield of alumina extraction obtained tend to decrease from $50.75 \%$ by using $3 \mathrm{~kg}$ of lime to $16.77 \%$ by using $9 \mathrm{~kg}$ of lime. Whereas, by varying reaction time between 1.0-2.5 hours, percent yield of alumina extraction tend to fluctuate in the range of $44.29-62.79 \%$ in which 1.5 hours of reaction time is the highest percent yield. By implementing four equation described above, weighing of the slurry in Mixer is not needed.

\section{ACKNOWLEDGEMENTS}

Thank to Ministry of Energy and Mineral Resources of Indonesia for funding research activity until this paper can be prepared. Thank is also conveyed to Mr. Kusna Wijaya and Mr. Ade Setia Permana for supporting this research activities including praparation and analysis all samples resulting from the research.

\section{REFERENCES}

Alcoa, 2016. Bauxite Interests, http://www.alcoa.com/alumina/en/info p age/bauxite interests.asp, downloaded on May $9^{\text {th }}, 2016$.

Chen, H-L., Lewellyn, M., Chamberlain, O., Heitner, H., Kula, F., Dai, Q., Franz, C., 2007. Sodalite Scale Control In Alumina Bayer Process, Corrosion 2007, 11-15 March, Nashville, Tennessee.
Donoghue, A. M, Frisch, N., Olney, D., 2014. Bauxite mining and alumina refiningprocess description and occupational health risks, J. Occup Environ Med. 2014 May; 56(5 Suppl):S12-7. doi: 10.1097/JOM

Faiers, A., 2015. Chemistry in perspective, Chapter 19: Chemistry Vs. Money (some inorganic industrial processes), Section 2: Inorganic, http://www.chembook.co.uk/chap19.htm, downloaded on May $9^{\text {th }}, 2016$.

Hond, R. D., Hiralal, I., Rijkeboer, A., 2007. Alumina yield in the bayer process past, present and prospects, The Minerals, Metals \& Materials Society, The Netherlands, downloaded on May $9^{\text {th }}$, 2016.

Kontopoulos, A., Panias, D., and Paspaliaris, I., 1997. Precipitation of monohydrate alumina in the Bayer process I. National Technical University Of Athens Universite Libre De Bruxelles Hellenic Alumina Industry Contract JOE3-CT950003. Publishable Final Report January 1996 to June 1997. Research funded in part by The European Commission in the framework of the Non Nuclear Energy Programme JOULE III.

Kopeliovich, D., 2012. Bayer process, http://www.substech.com/dokuwiki/doku. php?id=bayer_process, downloaded on May $9^{\text {th }}, 2016$.

Marsh, C., 2009. CFD modelling of alumina calciner furnaces. Seventh International Conference on CFD in the Minerals and Process Industries CSIRO. Melbourne. Australia 9-11 December 2009. E-mail address: cmarsh@engineeringCFD.com.

Oxana Fox, 2016. How to calculate percent solids by weight. http://www.ehow.com/how 7519269 cal culate-percent-solids-weight.html. downloaded on February $14^{\text {th }} .2016$.

Palmer, Sara J. and Frost, Ray L. and Nguyen, Tai M. 2009. Hydrotalcites and their role in coordination of anions in Bayer liquors: Anion binding in layered double hydroxides. Coordination Chemistry Reviews 253(1-2):pp. 250-267. Copyright 2009 Elsevier.

Pan, X.L., Yu, H.Y. Dong, K.W., Tu. G.F., and Bi, S.W., 2012. Pre-desilication and digestion of gibbsitic bauxite with lime in 
INDONESIAN MINING JOURNAL Vol. 19, No. 1, February $2016: 27$ - 38

sodium aluminate liquor. International Journal of Minerals, Metallurgy, and Materials, vol. 19, issue 11, p. 973-977.

Reyner-Canham G., 1996. Descriptive Inorganic Chemistry, W.H. Freeman and Company, Second printing, ISBN C7167-2819-2, p. 213-216

Smith, P., 2009. The Processing Of High Silica Bauxites-Review of Existing And Potential Processes. Hydrometallurgy, 98,162-176.

Tariq, M., Iqbal, M.M., Aziz, A., Shafiq, M., Sajid, M. and Mohammad, B., 2014. Recovery of alumina from Khushab bauxite by leaching with sulphuric acid and removal of iron impurity by ethanol, J.Chem.Soc.Pak., vol. 36, no. 4, p. 624629.

The International Aluminium Institute, 2012. Aluminium for future generations, http://www.slideshare.net/cominst75/alu minium-for-future-generations, downloaded on May $9^{\text {th }}, 2016$

Zhang, S. Du, H., Xu, H., Wang, S., Zhang, Y., 2009. Improved Ying precipitation of gibbsite from sodium aluminate solution by adding methanol. Hydrometallurgy 98 (2009) 38-44. journal homepage: www.elsevier.com/locate/.hydromet. 